\title{
A New Perspective on Delusional States - Evidence for Claustrum Involvement
}

\author{
Maria Cristina Patru ${ }^{1}$ and David H. Reser ${ }^{2 *}$ \\ 'Department of Psychiatry, Hôpitaux Universitaires de Genève, Geneve Switzerland, '2 Department of Physiology, Monash \\ University, Melbourne, Australia
}

Delusions are a hallmark positive symptom of schizophrenia, although they are also associated with a wide variety of other psychiatric and neurological disorders. The heterogeneity of clinical presentation and underlying disease, along with a lack of experimental animal models, make delusions exceptionally difficult to study in isolation, either in schizophrenia or other diseases. To date, no detailed studies have focused specifically on the neural mechanisms of delusion, although some studies have reported characteristic activation of specific brain areas or networks associated with them. Here, we present a novel hypothesis and extant supporting evidence implicating the claustrum, a relatively poorly understood forebrain nucleus, as a potential common center for delusional states.

OPEN ACCESS

Edited by:

Bernat Kocsis,

Harvard Medical School, USA

Reviewed by:

Sabina Berretta,

McLean Hospital, USA

Ami Citri,

The Hebrew University, Israel

*Correspondence:

David Reser

david.reser@monash.edu

Specialty section:

This article was submitted to

Schizophrenia,

a section of the journal

Frontiers in Psychiatry

Received: 23 July 2015

Accepted: 26 October 2015

Published: 09 November 2015

Citation:

Patru MC and Reser DH (2015)

A New Perspective on Delusional

States - Evidence for

Claustrum Involvement.

Front. Psychiatry 6:158.

doi: 10.3389/fpsyt.2015.00158
Keywords: claustrum, delusions, positive symptoms, psychosis, mesolimbic dopamine system

\section{INTRODUCTION}

Delusions are broadly categorized as a misapprehension of reality, which has a realistic character for the patient, and to which he or she adheres with conviction despite contradiction by reality, experience, or collective beliefs. Delusions are of particular diagnostic importance in schizophrenia, and current treatments, including antipsychotics, exhibit variable effectiveness against them $(1,2)$. Therapies for delusions that occur in non-schizophrenic psychiatric (e.g., bipolar disorder, depression, dementia, substance use) and neurological disorders (e.g., tumors, infectious, metabolic, traumatic, vascular, autoimmune disorders) are similar to those used to treat schizophrenia (e.g., antipsychotics), and exhibit similar levels of efficacy in all these disorders.

Delusions are a heterogeneous concept, with several semiotic entities (delusional feelings or mood, delusional perceptions, and delusional thoughts), systematization degrees (organization in a logical manner, with causal links, or not), modalities of elaboration (interpretative, imaginative, intuitive, or hallucinatory) and themes (delusions of reference, persecution, jealousy, guilt, hypochondriacal, grandeur, and so on). Varying degrees of delusional ideation are also found in the healthy population (3-6).

Although some experimental animal models of psychotic behavior are available [e.g., see Ref. (7)], it is nearly impossible to establish a concrete link between measures of overt responses in animals, such as paired pulse inhibition, conditioned avoidance, or latent inhibition, and changes in abstract representation of the external world by an individual (8). These limitations have led to slow progress in research surrounding delusions.

Despite numerous studies of patients with psychotic symptoms describing characteristic activation of specific brain areas or networks (9-17), there have been no detailed studies to date focusing specifically on delusions and their neural mechanisms. Here, we present a review of 
evidence obtained from a wide range of studies, employing a diverse array of analytical approaches, which has led to speculate that the claustrum, a relatively poorly understood forebrain nucleus, may be a critical link in the chain of causality for delusional states. Suggestive evidence of structural and/ or functional changes in the claustrum as a component of delusions, or psychotic symptoms more generally, has been widely reported. However, due to sparse information about the functional organization of the claustrum, and the difficulty of studying this nucleus in isolation, causality cannot be inferred from the existing literature. Thus, the proposed hypothesis necessarily rests upon indirect, and in some cases, non-specific evidence. Our purpose in this review is to familiarize clinicians and researchers with the current (relatively poor) state of understanding of claustrum structure and function, and to introduce testable and accessible research questions that could be employed to evaluate this hypothesis.

The claustrum is a deep gray matter brain structure, first identified in the eighteenth century (18). Many researchers have since commented on its unusual anatomy, ontogeny, histology, vasculature, and cytochemistry. However, the function or functions of the claustrum remain uncertain (19). The convoluted shape and relatively inaccessible location of the claustrum render it difficult to study using conventional methods, though recent advances in structural and functional imaging have identified claustrum dysfunction in a number of psychiatric symptoms and diseases. In primates, the claustrum is thin in cross section, but broad and elongated along the rostral-caudal and dorsal-ventral axes (Figure 1). Targeted lesions, microinjections of tracer or drugs, and placement of recording electrodes for electrophysiology are complicated by the virtual certainty of injury to adjacent structures, including the insular cortex, external and extreme capsules, and striatum.

Synthesis of knowledge about possible relationships between the claustrum and delusions is complicated by several factors, including (1) the relative paucity of studies that focus on the claustrum, as opposed to its inclusion in a long list of "accessory structures," which exhibit changes in a given condition; (2) the even larger number of functional studies in which the claustrum is subsumed in activity assigned to the anterior insula and/or striatum; and (3) the lack of a clear framework for claustrum function in normal behavior [reviewed in Smythies et al. (20)]. All of the major current hypotheses regarding claustrum function, described in detail in Box 1, involve mental processes that are essential for accurate interpretation of sensory information in the context of past experiences. This "reality testing" function is compromised across delusions, regardless of the modality or specific features of the delusion.

Here, we hypothesize a role for claustrum dysfunction in the pathophysiology of delusions across several psychiatric disorders. This hypothesis is based on the widespread cortical connectivity of the claustrum and on the common feature of delusional symptoms, which is impairment of the ability to accurately assess the "validity" of perceptual judgments regarding mental representations of the external world. Breakdown of this process permits patients to accept, even embrace, constructs of reality that contain implausible, or even bizarre characterizations.

\section{STRUCTURAL CONNECTIVITY, ELECTROPHYSIOLOGICAL, AND FUNCTIONAL STUDIES OF THE CLAUSTRUM}

A prominent feature of the claustrum in all species studied to date is its pervasive and reciprocal connectivity with most areas of the cerebral cortex. In both rodents and humans, the claustrum is among the most connected forebrain structures in the brain (28), with extensive cortical and subcortical projections. The organization of structural connections as defined by tracer and/ or electrophysiological studies in cats and monkeys shows both rostro-caudal and medio-dorsal topography of connections with sensory cortex. In the visual domain, retinotopic connections with striate cortex are observed in dorsal-caudal claustrum (29, 30), while auditory representation [mid and caudal-ventral, (31)] and somatomotor representations (32) have also been described. Extensive projections to the PFC have also been reported, predominantly localized in the mid-ventral and rostral claustrum [(23); reviewed in Druga (33)].

In a detailed microdissection and tractography study of postmortem human brains, Fernandez-Miranda et al. (34) identified two prominent projection pathways emanating from the claustrum: a dorsal pathway containing the bulk of the fibers connected with the sensory and motor areas of cortex, and a ventral pathway containing uncinate fasciculus fibers, which transit and merge with the ventral claustrum gray matter. Interestingly, that study also reported that cortico-claustral fibers account for the majority of axons in the external capsule, with a much smaller group connecting with the putamen. These claustro-cortical fibers also exhibited spatial topography, with the caudal portions of cortex connected with the more caudal section of the dorsal claustrum, and the rostral cortical connections comprising the anterior external capsule fibers and anterior dorsal claustrum tracts. Tractography studies in humans largely support the patterns of connectivity described above, with some refinements. Milardi et al. (35) identified four principal white matter tracts connecting the claustrum with other structures, suggesting some of these may have been unavoidably ablated by the microdissections of Fernandez-Miranda et al. The additional projection pathways identified by Milardi et al. include a medial claustrum-basal ganglia pathway and interhemispheric projections terminating in the contralateral claustrum and cortex.

Topography of claustrum-cortex projections was also reported by Morys et al. (36), based on a detailed postmortem study of nine adult brains with ulegyria (malformation characterized by localized gyral hypotrophy following ischemic injury in the neonatal period). They noted a correlation between pathological reduction in the size of the frontal lobes and the anterior claustrum, and between the reduced size of the parieto-occipital lobes and the central and posterior claustrum.

Electrophysiological studies of claustrum function are rare in the literature, which is perhaps not surprising given the difficult surgical approach and unusual geometry of this structure. Morys and colleagues $(37,38)$ have studied sensory evoked potentials (SEPs) in the ipsilateral cortex, both in patients with unilateral 


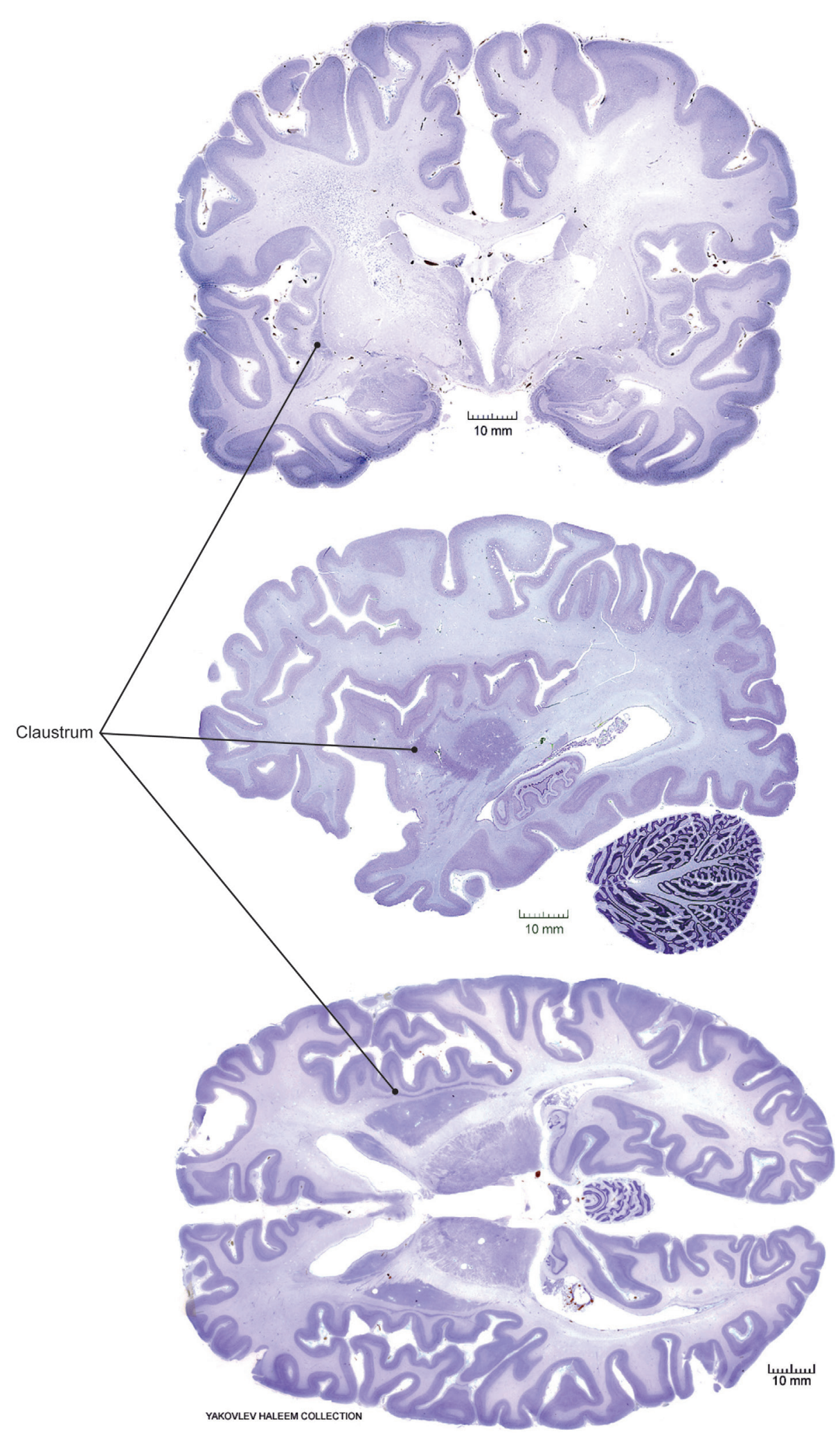

FIGURE 1 | Claustrum location in human brain. Coronal (top), sagittal (middle), and horizontal (bottom) views from Nissl-stained postmortem sections obtained from a public repository. Solid circles indicate the position of the claustrum in each view. Note, sections are not taken from the same three-dimensional position, i.e., sections are not registered with respect to the whole brain structure. Images adapted with permission from http://www.brains.rad.msu.edu, and http://brainmuseum.org, supported by the US National Science Foundation. 
BOX 1 | Recent hypotheses surrounding claustrum function(s).

Here, we describe the major working hypotheses regarding claustrum function that have been published in the past decade. We recognize (1) that there is considerable overlap in the roles proposed here, (2) that these hypotheses are not mutually exclusive, and (3) that all of these proposals may well be incomplete, or flat wrong. However, these models underpin much of the current experimental work surrounding the neuroanatomical, neurophysiological, and neurochemical properties of the claustrum, and delusional symptoms could arise from dysfunction of any of these processes.

1. The "orchestra conductor" - first proposed by Crick and Koch (21), this influential hypothesis suggests that the claustrum acts to synchronize activity across the various timescales of sensory modalities, allowing for generation of a unified percept of the external world (sensory binding). The model rests on the central location of the claustrum in each cerebral hemisphere, as well as its high intrinsic connectivity and fairly uniform cytoarchitecture, all of which could act to smooth out disparities in temporal activity occurring within each modality that result from the same environmental source, such as the size and direction of motion (visual), hoofbeats (auditory), and vibration (somatosensory) of a charging bull, allowing it to be perceived as a single object.

2. Sensory integration/coincidence detection - proposed by Smythies et al. (22), this hypothesis has undergone several refinements. In its most recent iteration, the claustrum functions as a coincidence or mismatch detector, by means of amplification of oscillatory activity in reverberating claustro-cortical circuits. Oscillatory activity generated in disparate cortical or subcortical regions could presumably be reinforced, either enhancing the perceptual salience of a target, or as a function of target salience (causality is not yet clear in this case).

3. Modulation/switching of cortical functional networks - First outlined by Reser et al. (23), this hypothesis is based on the connectional anatomy of claustro-cortical circuits in the prefrontal cortex (PFC) of the monkey. Recent work (24), has shown that the transition between increased synchrony of the (task negative) default mode, and (task positive) central executive network is likely mediated by activation of a third network, the salience network described by Seeley et al. (25). This switching role for the salience network has recently been confirmed by Goulden et al. (26), and the area templates used for both the salience and central executive networks in that study clearly overlap the claustrum, especially in the left hemisphere [(26), their Figure 1]. Prefrontal areas involved in both the default mode and central executive networks exhibit overlapping claustrum representations, and it is interesting to note that stimulus salience also figures prominently in hypotheses 2 (above), and 4 (below). Note that imaging studies published to date have ascribed activity in the salience network to the insular cortex (immediately adjacent to the claustrum), rather than the claustrum. Full explication of this disparity is outside the scope of this work, but the connectional anatomy of $\mathrm{New}$
World monkey species suggest that the claustrum is a plausible hub for this network.

4. Modulation of selective attention - Recent theoretical work and review of experimental data led Goll et al. (27) to propose that the claustrum is a key locus for modulation of selective attention. Crucially, their model incorporates both the laminar circuitry of the cerebral cortex and the modulation of claustro-cortical circuits via clearly described subcortical pathways, which facilitates experimental testing of the model. In particular, their description of the putative circuitry in the rodent brain will allow for modern molecular and genetic tools to be applied to the claustrum in ways not previously feasible.

lesions exclusively of claustrum or other parts of the brain (simultaneous lesions were not observed in the studied population) and in healthy subjects. In subjects with unilateral isolated claustrum injuries, after stimulation of the median nerve, SEPs were absent from the ipsilateral cortex when controlateral claustrum was injured. This observation was not present in patients with unilateral somatosensory-parietal, somatosensory-thalamic relay nuclei, or internal capsule lesions. The authors concluded that the claustrum exerts influence upon the contralateral somatosensory cortex. We are not aware of equivalent testing performed in any other modality, so this remains an isolated finding, but recently claustro-cortical fibers crossing the midline were demonstrated in humans (35). Our observations indicate, however, that the majority of claustrum-PFC connections are ipsilateral in the primate brain (23).

In a recent and tantalizing case report, Koubeissi and colleagues described electrical stimulation mapping of the claustrum with depth electrodes in a 54-year-old female patient with intractable epilepsy [seizure origin in left amygdala; (39)]. They reported that a reversible stimulation of the left claustrum elicited interruption of awareness for the duration of the stimulation, followed by a return to normal function, comparable to an absence-type seizure. No similar effect was observed when electrodes in the adjacent insula or putamen were activated. Although restricted to a single case, this report has elicited new interest in the claustrum as a potential causal or permissive structure in the origin of conscious awareness.

\section{CLAUSTRUM MORPHOLOGY - CONSIDERATIONS FOR IMAGING STUDIES}

A claustrum or claustrum-like structure has been described in all placental mammals studied to date [reviewed in Smythies et al. (20)]. A full comparison of the known claustrum anatomy across species is beyond the scope of this work, but we will briefly describe the prominent features of this structure, especially those that will aid in the design or interpretation of future research studies. Readers seeking more detailed exploration of the comparative aspects of claustrum functional organization are referred to the recent Frontiers in Systems Neuroscience Special Topics 
collection edited by Deutch and Mathur (40) http://journal. frontiersin.org/researchtopic/1745/the-claustrum-charting-away-forward-for-the-brains-most-mysterious-nucleus.

The claustrum sits in a notoriously inaccessible location, extending vertically like a corrugated sheet between the external and extreme capsules, in the anterior fronto-temporal region. Morphologically, the claustrum follows the concavity of the insular cortex, while its internal curvature follows the convexity of the putamen. Although the gray matter volume of this structure has been examined using imaging methods, the precise anatomical boundaries remain in dispute in both human and animal subjects $(23,41,42)$. One consequence of this morphological indeterminacy is the difficulty of ascribing activity detected using functional imaging to claustrum-containing voxels, especially at the magnetic field strengths typical of current clinical imaging systems (43).

In a postmortem imaging study based on data from the Visible Human Project, the volume of the claustrum was asymmetrical, with $\sim 15-20 \%$ greater volume in the right hemisphere (44), corresponding to an average volume of $829 \mathrm{~mm}^{3}$ on the right side and $706 \mathrm{~mm}^{3}$ on the left. This in turn corresponded to $\sim 10 \%$ of the volume of the overlying insular cortex. Recently, Torgerson et al. (45) reported a similar degree of asymmetry (right hemisphere is $\sim 13 \%$ less than left hemisphere volume) in an fMRI/ DTI study of 100 neurologically normal subjects, though the absolute volumes reported in that study were somewhat smaller than the claustrum volume reported by Kapakin (44). Milardi and colleagues (35) reported consistently less hemispheric asymmetry in their diffusion imaging study of 10 volunteers, with the claustrum volume in male subjects closely matching the volumes reported by Kapakin (44), and the volumes of the female subjects more closely aligned with the reported volumes of Torgerson et al. (45). While these differences are most likely methodological, or due to restricted sample sizes, the variation across studies should temper interpretation of volumetric findings in pathological conditions until a better estimate of the normal claustrum volume is obtained (preferably at several different life stages).

\section{FUNCTIONAL CONNECTIVITY OF THE CLAUSTRUM}

It is increasingly apparent that the claustrum is a hub region of one or more functional networks in the brain, and understanding its function will require emplacement in a networked context. These networks have been identified largely from synchronous oscillations of blood flow or field potential activation during awake "resting states" in which subjects are not engaged in other tasks [reviewed in Keilholz (46)]. The best characterized of these networks include the default mode network [(47); reviewed in Raichle (48)], the salience network $(25,49)$, and the central executive network $(25,50)$. The hub areas of each of these networks have dense claustrum connectivity, and importantly, homologs of the major networks have been identified in non-human primates (51, 52) and in rodents (53-55), allowing for controlled experimental investigation of network properties.
Recently, Satterthwaite and Baker (56) reviewed a growing body of evidence that is converging on abnormalities in development of these networks as a risk factor for psychosis. Specifically, they outline how failure of these networks to segregate from a highly overlapping pattern in childhood into a heterogeneous group of networks with high internal connectivity represents a characteristic pattern in adults with psychotic symptoms. Analysis of the structural connectivity of the claustrum has shown that it occupies a position within several key functional networks $(45,57)$, which is consistent with both the observed functional connectivity of the networks and with our speculation that damage to the claustrum could precipitate or permit acceptance of delusional thoughts (see hypotheses 3 and 4 in Box 1). In proposing this hypothesis, we acknowledge up front that disruption of these networks has been implicated in numerous other disorders, many of which do not include delusions among their symptoms, so there are obviously factors could impact the function of these networks apart from any claustrum involvement.

Using structural and diffusion tensor neuroimaging in a large sample $(N=100)$ of healthy subjects, Torgerson and colleagues found that the claustrum had the highest connectivity density among all examined brain regions (45). Graph theoretical analyses revealed that the claustrum is a primary contributor to global brain network architecture, and that significant connectivity dependencies exist between the claustrum, frontal lobe, and cingulate regions.

Recently, an analysis of over 16,000 structural connections between brain areas in rats, as identified by neuroanatomical tracer injections, included the claustrum among the three most densely connected structures in the forebrain [along with the medial and lateral subdivisions of the entorhinal cortex; (28)]. No similar analysis of tracer studies conducted in the primate claustrum is available, but it is likely that the claustrum is among the most highly connected primate brain regions as well. This rich connectivity has been the foundation of most hypotheses regarding claustrum function $(20,21,23)$.

\section{EVIDENCE FOR CLAUSTRUM INVOLVEMENT IN DELUSIONAL PROCESSES}

Only a few clinical studies have described the neurological lesions or conditions where the claustrum was the sole region of involvement $(58,59)$. This may support the idea that dysfunction in the claustrum results primarily in disruption of higher behavioral and cognitive functions associated with the functional networks described in the previous section, rather than a specific, unitary deficit (42). Consistent with this pattern, Jacobson-McEwen et al. (60) found decreased intrinsic functional connectivity between the claustrum and dorsal anterior cingulate cortex (hubs of the default mode and salience networks, respectively) in adolescents exhibiting psychotic symptoms (delusions and hallucinations). Alternatively, it is possible that isolated spontaneous lesions of the claustrum are exceedingly rare, with lesions in this area likely also to include damage to the surrounding white matter, insular cortex, and/or putamen. 
Currently, only indirect evidence exists for claustrum dysfunction in delusions, due in part to the paucity of studies in human subjects that feature targeted investigation of the claustrum, and in part to lack of an explicit animal model of delusions. Volumetric studies (see Table 1) have been especially suggestive. In schizophrenia, the intensity of delusions is inversely related to the volume of the left claustrum and right insula (61). Reduced claustrum volume on the left side was also positively correlated with the presence of delusions in patients suffering from Alzheimer's disease (62). In that study, reduced gray matter volume in the left insula was correlated with agitation, and reduced putamen volume was associated with apathy, but neither area exhibited a significant correlation with the presence of delusions. Gray matter volume reduction was observed in the insular region of patients with delusions associated with bipolar disorder (14). Our interpretation of the Radaelli et al. study suggests that there may also have been claustrum involvement in the affected region (see, e.g., their Figure 1), though the authors did not comment on this. It is of course possible that the observed gray matter reductions could be associated with other aspects of the disorder, such as mania or depression, but this is unlikely, as the retrospective study design specifically compared patients with a history of delusions to a matched clinical sample with no past delusions, rather than to a healthy control population. The authors extensively discussed the importance of dysregulation of salience processing for delusions, and importantly, the population they studied specifically excluded subjects with hallucinations. Wolf et al. (63) also reported decreased gray matter volume in the insular region, accompanied by increased white matter volume in the external and extreme capsule region, in 16 non-demented, non-schizophrenic patients exhibiting delusional infestation. Close examination of the data presented in that study suggests involvement of the claustrum as well, which would also be consistent with increased white matter volume (i.e., possibly due to loss of the intervening claustrum gray matter - see their Figure 1B, middle), though the authors again did not specifically call out the claustrum as an affected structure.

More recently, in a postmortem study, Bernstein et al. (64) found bilaterally reduced claustral volumes associated with both schizophrenia and major depressive disorder. Although the overall number of brains examined was relatively small, especially for major depressive disorder, several interesting patterns were evident in this study. In particular, the severity of positive symptoms (delusions and hallucinations) was correlated with the degree of volume loss in the post mortem claustrum, showing that significantly smaller volumes are present in subjects with paranoid schizophrenia, but not in those with the diagnosis of residual schizophrenia, which is consistent with the volumetric results described by Cascella et al. (61).

One possibility which should be explored in future studies is that the insula and claustrum may act in concert, or may both be components of a larger network associated with salience processing or "reality testing." This network would likely include other subcortical nuclei such as the amygdala, which also has widespread connectivity with the medial prefrontal areas and anterior cingulate cortex, and which (along with voxels in the insula-claustrum region) exhibits increased activity associated with referential ideation in people experiencing delusions (65). Strong reciprocal connectivity between the anterior claustrum and the amygdala (as well as the insula) has been shown in rats, and seizures induced by kindling in the anterior claustrum resemble seizures generated in the amygdala (66). Damage affecting the claustrum, insula, or amygdala, alone, or more likely, in concert, could lead to or potentiate delusional ideas by disruption of functional connectivity in such a network.

\section{CLAUSTRUM LESIONS}

An obvious approach to examining a putative link between claustrum function and the presence of delusional thinking is assessment of the relationship between the occurrence of delusions and damage to the claustrum in said patients (see Table 2). However, spontaneous lesions restricted to the claustrum are exceedingly rare. Developmentally, agenesis of claustrum is associated with other severe brain malformations, with poor prognoses $(67,68)$. Isolated bilateral claustrum lesions in adults are similarly rare, and we found only two in the literature, one viral (58) and one non-viral (59) transitory encephalopathy. In both cases, patients presented with psychotic symptoms.

TABLE 1 | Clinical/imaging studies reporting delusions associated with volumetric or morphological changes in the claustrum.

\begin{tabular}{|c|c|c|c|}
\hline Reference & Study & $\begin{array}{l}\text { Within study prevalence of } \\
\text { delusions }\end{array}$ & Results \\
\hline Bruen et al. (62) & $\begin{array}{l}\text { In vivo, MRI: } 31 \text { patients/ } \\
\text { Alzheimer's disease }\end{array}$ & $16 \%$ Of patients & $\begin{array}{l}\text { High delusion scores correlated significantly with low grey mater } \\
\text { density values in: right inferior frontal gyrus; right inferior parietal } \\
\text { lobule, left inferior and medial frontal gyri, left claustrum }\end{array}$ \\
\hline Cascella et al. (61) & $\begin{array}{l}\text { In vivo, MRI: } 43 \text { patients/ } \\
\text { schizophrenia }\end{array}$ & $70 \%$ Of patients & $\begin{array}{l}\text { Significant inverse correlations between ratings of the severity of } \\
\text { delusions and volumes of: the left claustrum and the right insula } \\
\text { No significant correlation between cerebral gray mater volume and } \\
\text { ratings of hallucinations }\end{array}$ \\
\hline Bernstein et al. (64) & $\begin{array}{l}\text { Postmortem: } 14 \text { patients/ } \\
\text { schizophrenia: } 15 \text { normal } \\
\text { control subjects }\end{array}$ & $\begin{array}{l}57 \% \text { Of patients ( } 8 / 14 \text { patients) } \\
\text { exhibit positive symptoms (no } \\
\text { specific data for delusions and } \\
\text { hallucinations frequency) }\end{array}$ & $\begin{array}{l}\text { Estimated claustrum volume reductions were between } 25 \text { and } 30 \% \\
\text { of controls. Moreover, when dividing the schizophrenia group (14 } \\
\text { patients) into "paranoid schizophrenia" ( } 8 \text { patients) and "residual } \\
\text { schizophrenia" ( } 6 \text { patients) subgroups, the significant bilateral } \\
\text { volume reductions in schizophrenia subjects were found to be } \\
\text { (mainly) caused by the paranoid schizophrenia group }\end{array}$ \\
\hline
\end{tabular}


TABLE 2 | Case reports and individual findings from congenital, spontaneous, and iatrogenic claustrum lesions.

\begin{tabular}{|c|c|c|c|c|c|c|c|}
\hline Reference & $\begin{array}{l}\text { Claustrum } \\
\text { Lesions }\end{array}$ & $\begin{array}{l}\text { Other affected brain } \\
\text { areas }\end{array}$ & Diagnosis & $\begin{array}{l}\text { Claustrum lesion } \\
\text { mechanism }\end{array}$ & $\begin{array}{l}\text { Psychiatric and non-psychiatric } \\
\text { symptoms }\end{array}$ & $\begin{array}{l}\text { Evolution of } \\
\text { psychiatric } \\
\text { symptoms }\end{array}$ & Notes \\
\hline Dodgson (67) & $\begin{array}{l}\text { Absence of } \\
\text { dorsal claustrum }\end{array}$ & $\begin{array}{l}\text { Bilateral insular } \\
\text { microgyria, abnormal } \\
\text { frontal and temporal } \\
\text { sulci adjacent to the } \\
\text { insula }\end{array}$ & Mental retardation & Brain malformations & Mental retardation & Not commented upon & \\
\hline Ishii et al. (58) & $\begin{array}{l}\text { Bilateral } \\
\text { claustrum }\end{array}$ & Nil & $\begin{array}{l}\text { Viral (mumps) } \\
\text { encephalitis }\end{array}$ & $\begin{array}{l}\text { Edema } \\
\text { Inflammatory? }\end{array}$ & $\begin{array}{l}\text { Confusion, visual and auditory } \\
\text { hallucinations, epilepsia }\end{array}$ & Reversible & \\
\hline $\begin{array}{l}\text { McKay and } \\
\text { Cipolotti (69) }\end{array}$ & Right claustrum & $\begin{array}{l}\text { Right insula, adjacent } \\
\text { white matter, less severe } \\
\text { changes in left insular } \\
\text { cortex }\end{array}$ & $\begin{array}{l}\text { Herpes simplex } \\
\text { encephalitis }\end{array}$ & $\begin{array}{l}\text { Edema } \\
\text { Inflammatory? } \\
\text { Immune reaction? }\end{array}$ & Cotard delusion status epilepticus & Reversible & \\
\hline $\begin{array}{l}\text { Sperner et al. } \\
\text { (59) }\end{array}$ & $\begin{array}{l}\text { Bilateral } \\
\text { claustrum }\end{array}$ & $\begin{array}{l}\text { bilateral External } \\
\text { capsuale }\end{array}$ & $\begin{array}{l}\text { Transitory non- } \\
\text { viral encephalitis }\end{array}$ & $\begin{array}{l}\text { Edema } \\
\text { Inflammatory? }\end{array}$ & Psychotic symptoms & Reversible & \\
\hline $\begin{array}{l}\text { Shoji et al. } \\
(70)\end{array}$ & $\begin{array}{l}\text { Bilateral } \\
\text { claustrum }\end{array}$ & $\begin{array}{l}\text { Both hippocampi, both } \\
\text { amygdalae }\end{array}$ & $\begin{array}{l}\text { Non-herpetic } \\
\text { acute limbic } \\
\text { encephalitis }\end{array}$ & $\begin{array}{l}\text { Edema } \\
\text { Inflammatory? } \\
\text { Immune reaction? } \\
\text { CSF positive for anti- } \\
\text { GluR€2 IgG and IgM } \\
\text { antibodies }\end{array}$ & $\begin{array}{l}\text { Delirious state, restlessness, } \\
\text { palpitation, seizures }\end{array}$ & Reversible & \multirow{3}{*}{$\begin{array}{l}\text { Patients with non-herpetic acute limbic } \\
\text { encephalitis (NHALE) often manifest behaviora } \\
\text { disorders, incoherent speech, delusions and } \\
\text { hallucinations. This it to put the presence of } \\
\text { auto antibody against glutamate receptor } \\
\text { in NHALE could lead to a malfunctioning } \\
\text { glutamate systems and then the disruption of } \\
\text { dopaminergic pathways, as suggested in the } \\
\text { glutamate model of delusions }\end{array}$} \\
\hline $\begin{array}{l}\text { Ishida et al. } \\
\text { (71) }\end{array}$ & $\begin{array}{l}\text { Bilateral } \\
\text { claustrum }\end{array}$ & Right hippocampus & $\begin{array}{l}\text { Non-herpetic } \\
\text { acute limbic } \\
\text { encephalitis }\end{array}$ & $\begin{array}{l}\text { Edema } \\
\text { Inflammatory? } \\
\text { Immune reaction? } \\
\text { CSF positive for auto } \\
\text { antibody against } \\
\text { glutamate receptor }\end{array}$ & $\begin{array}{l}\text { Headache, convulsion, } \\
\text { consciousness disturbance, ataxia, } \\
\text { cold-like symptoms. disturbance of } \\
\text { short-term memory and a change } \\
\text { of character }\end{array}$ & $\begin{array}{l}\text { Reversible unless } \\
\text { memory disturbances }\end{array}$ & \\
\hline $\begin{array}{l}\text { Matsuzono } \\
\text { et al. (72) }\end{array}$ & $\begin{array}{l}\text { Bilateral } \\
\text { claustrum, }\end{array}$ & $\begin{array}{l}\text { Medial of frontal lobe, } \\
\text { periventricular region }\end{array}$ & $\begin{array}{l}\text { Non-herpetic } \\
\text { acute limbic } \\
\text { encephalitis }\end{array}$ & $\begin{array}{l}\text { Edema } \\
\text { Inflammatory? } \\
\text { Immune reaction? } \\
\text { CSF positive for auto } \\
\text { antibody against } \\
\text { glutamate receptor }\end{array}$ & $\begin{array}{l}\text { Delusional ideas and } \\
\text { hallucinations, but not seizures } \\
\text { (personal communication to CP) } \\
\text { Parkinsonism, myoclonus }\end{array}$ & Reversible & \\
\hline
\end{tabular}


TABLE 2 | Continued

\begin{tabular}{|c|c|c|c|c|c|c|c|}
\hline Reference & $\begin{array}{l}\text { Claustrum } \\
\text { Lesions }\end{array}$ & $\begin{array}{l}\text { Other affected brain } \\
\text { areas }\end{array}$ & Diagnosis & $\begin{array}{l}\text { Claustrum lesion } \\
\text { mechanism }\end{array}$ & $\begin{array}{l}\text { Psychiatric and non-psychiatric } \\
\text { symptoms }\end{array}$ & $\begin{array}{l}\text { Evolution of } \\
\text { psychiatric } \\
\text { symptoms }\end{array}$ & Notes \\
\hline $\begin{array}{l}\text { Chakraborty } \\
\text { et al. (73) }\end{array}$ & Left claustrum & $\begin{array}{l}\text { Multiple cortical (insular, } \\
\text { medial and lateral } \\
\text { frontal cortex), and } \\
\text { periventricular (caudate } \\
\text { head) discrete ring } \\
\text { enhancing lesions and } \\
\text { associated surrounding } \\
\text { edema }\end{array}$ & $\begin{array}{l}\text { Multiple } \\
\text { parenchymal } \\
\text { neurocysticercosis }\end{array}$ & $\begin{array}{l}\text { Oedéma } \\
\text { Inflammatory? }\end{array}$ & $\begin{array}{l}\text { Delusion of jealousy left-sided } \\
\text { hemiplegia }\end{array}$ & Reversible & \\
\hline $\begin{array}{l}\text { McMurtray } \\
\text { et al. (74) }\end{array}$ & Left claustrum & $\begin{array}{l}\text { Left basal ganglia with } \\
\text { adjacent edema likely } \\
\text { affecting the corona } \\
\text { radiate and possibly } \\
\text { extending to the optic } \\
\text { radiations } \\
\text { Small periventricular } \\
\text { hyperintensities }\end{array}$ & $\begin{array}{l}\text { Hemorrhagic } \\
\text { stroke }\end{array}$ & $\begin{array}{l}\text { Necrosis? } \\
\text { Perinecrotic edema }\end{array}$ & $\begin{array}{l}\text { Neurological impairment, visual } \\
\text { and auditory hallucinations, and } \\
\text { delusions of rotting/decaying of the } \\
\text { right (paralyzed) side of his body } \\
\text { similar to a Cotard delusion }\end{array}$ & $\begin{array}{l}\text { Reversible with } \\
\text { antipsychotic } \\
\text { medications }\end{array}$ & \\
\hline $\begin{array}{l}\text { Turkalj et al. } \\
\text { (75) }\end{array}$ & Left claustrum & $\begin{array}{l}\text { A } 10 \mathrm{~cm} \text { tubular area } \\
\text { of posttraumatic } \\
\text { encephalomalacia of } \\
\text { the left hemisphere (left } \\
\text { orbitofrontal region, } \\
\text { insula, putamen, deep } \\
\text { white matter and parietal } \\
\text { lobe with consecutively } \\
\text { slightly enlarged left } \\
\text { lateral ventricle) }\end{array}$ & $\begin{array}{l}\text { Stabbing injury } \\
\text { from a billiard } \\
\text { stick }\end{array}$ & $\begin{array}{l}\text { Necrosis? } \\
\text { Post traumatic } \\
\text { gliosis } \\
\text { Edema? }\end{array}$ & $\begin{array}{l}\text { Delusions with paranoid and } \\
\text { religious content accompanied by } \\
\text { visual hallucinations, anosognosia, } \\
\text { bradypsychia, anhedonia, } \\
\text { depressed mood disinhibited } \\
\text { behavior, and progressive social } \\
\text { withdrawal, left eye mydriasis }\end{array}$ & Reversible & \\
\hline Sener $(76,77)$ & $\begin{array}{l}\text { "Bright claustrum } \\
\text { sign" (T2 } \\
\text { claustrum hyper } \\
\text { intensity) }\end{array}$ & - & $\begin{array}{l}\text { Wilson's disease } \\
\text { (WD) }\end{array}$ & $\begin{array}{l}\text { Oedéma } \\
\text { Inflammatory? }\end{array}$ & $\begin{array}{l}\text { Neurological symptoms, no } \\
\text { remarks about psychiatric } \\
\text { symptoms }\end{array}$ & - & $\begin{array}{l}\text { Delusional disorders and schizophrenia-like } \\
\text { psychosis have also been associated with WD } \\
\text { (78-81) }\end{array}$ \\
\hline
\end{tabular}


In other clinical cases presented in the literature (see Table 2), the claustrum is far from being the only affected cerebral structure. For instance, in cases of non-herpetic acute limbic encephalitis (NHALE) with bilateral claustrum lesions, patients experienced psychotic symptoms $(70,72)$, the claustrum damage occurred alongside lesions of other limbic structures. This precludes inference of a causal role for the claustrum in the observed symptoms, including delusions, where present, but offers guidance regarding which structures may present useful experimental targets for further exploration.

Somewhat surprisingly, Duffau et al. (82) reported that in a relatively large cohort of patients $(N=42)$, unilateral removal of the claustrum (and typically the overlying insula) did not generally produce sensory, motor, or cognitive deficits, and the majority of patients returned to near normal function (although criteria for normal function were not detailed). This suggests that there is some compensatory capacity between the claustrums of different hemispheres, though the extent of compensatory function remains uncertain, and will require more specific experiments. In subsequent sections, we will consider the available research data surrounding the functional organization of the claustrum, and its potential roles in normal and pathological brain function.

\section{HYPOTHESES REGARDING PUTATIVE MECHANISMS FOR CLAUSTRUM (DYS) FUNCTION IN DELUSIONS}

Over the last 30 years, explanations for psychiatric pathologies in general and the genesis of delusions in particular, have migrated from philosophical, to biological, and subsequently to neurocomputational models. Although there are strongly suggestive radiological or anatomical data that implicate claustrum dysfunction in delusions $(61,62,64)$, a compelling theoretical model for a biochemical or physiological mechanism of claustrum involvement in delusional pathologies has yet to be elucidated. Several candidate neurochemical pathways are outlined below, as well as possible neurocomputational mechanisms.

\section{DOPAMINE AND GLUTAMATE MODEL}

Current pharmacological and neurochemical models of delusions include the dopaminergic (DA) and glutamate pathways. The DA model explains why drugs currently used in treatment for patients with delusions, independent of causal pathology, are mainly dopamine antagonists which act inter alia at the level of D2 receptors on the mesolimbic DA pathway. The glutamate model suggests that malfunctioning glutamate systems lead to disruption of DA pathways, acting as an upstream agent in the pathophysiology of delusions $(83,84)$.

Although not well studied, there are some apparent links between the claustrum and the pharmacological model of delusions (e.g., the glutamate model and mesolimbic DA pathway; Box 2). As alluded to previously, some patients suffering from NHALE present with bilateral claustrum lesions and such psychotic symptoms as hallucinations and delusions $(70,72)$.
Furthermore, NMDA receptors are moderately expressed in the claustrum of New World monkeys (85) and strongly expressed in rat and human claustrum (86).

Direct DA modulation of claustrum cells is possible but does not appear to be a dominant influence based on the neurochemical architecture. Receptor autoradiography has shown DA receptors (D2-type) are present at light-moderate levels ( $\sim 3 \%$ of putamen strength) in the claustrum in postmortem human brains (96), and moderate-heavy expression of D2 mRNA has been reported in the rhesus monkey claustrum (97). Other DA receptor subtypes have not been reported at significant levels in the primate claustrum. However, the claustrum has anatomical connections with most of the components of the mesolimbic DA system and could modulate this pathway via excitation or indirect inhibition of mesolimbic pathway components at multiple levels. For example, the claustrum receives projections from the VTA (33) and projects to the nucleus accumbens $(33,66,98)$.

\section{KAPPA OPIOID RECEPTOR MODEL}

A better candidate for DA modulation of the claustrum may be found in the kappa opioid receptor (KOR) system. Kappa opioid receptors are densely expressed in the claustrum of rodents (99), Old World $(100,101)$ and New World (102) monkeys, and humans $(103,104)$, and it has been suggested that the hallucinogenic, delusionogenic, and psychotomimetic effects of the kappa opioid agonist salvinorin-A may be due to over-activation of the claustrum kappa receptor population (105). Much work remains to be done with respect to the psychopharmacology of the claustrum, and it should be noted that there is some evidence that salvinorin-A effects could be partially mediated by non-opioid specific activation of, e.g., the cerebellum (106).

\section{BOX 2 | Dopamine and glutamate models of delusions.}

At a psychopharmacological/neurotransmitter level, there are two main theories thought to account for delusions: the dopaminergic and glutamate models. The DA theory explains why drugs currently used in treatment for patients with delusions, independent of the causal pathology, are mainly DA antagonists which act inter alia at the level of D2 receptors on the mesolimbic DA pathway (MLDA). The glutamatergic model suggests that malfunctioning glutamate systems impacts the dopamine system and thus plays a critical, but indirect, role in the pathophysiology of delusions.

Glutamatergic modulation of the dopamine pathway is thought to be mediated via pyramidal cells in the prefrontal cortex (PFC) and ventral hippocampus, projecting locally on parvalbumin inhibitory interneurons (PV-IN) via glutamate NMDA postsynaptic receptors. The PV-IN, in turn, inhibits pyramidal cells via GABA-A receptors $(83,87)$. Insufficient inhibition of PFC pyramidal cells has been suggested as a pathway for excessive release of glutamate in the ventral tegmental area (NTA), leading to excess dopamine release in nucleus accumbens (88). Mesolimbic dopamine hyperactivity is implicated in delusions (89-91), as evidenced by the observation that phencyclidine and ketamine, both of which are known to cause delusions (92), affect glutamatergic neurotransmission in PV-IN of the PFC $(93,94)$. The glutamate model is further supported by the nearly uniform co-occurrence of delusions with NHALE (95), an encephalitis characterized by the presence of anti-glutamate (NMDA) receptor antibodies in the blood and/or the cerebrospinal fluid, and in which delusions are present in $90 \%$ of diagnosed patients. 
Exploration and elucidation of claustrum effects on various transmitter systems and consequent influence on psychotic symptoms will require increased awareness of the claustrum on the part of researchers and clinicians, and design of studies to specifically monitor the claustrum in psychiatric conditions. Enhancement of this awareness is a key objective of this review.

\section{SENSORY GATING AND ATTENTION MODEL}

Sensory gating is the ability to filter out irrelevant information from environmental stimuli, and thus reduce the load of redundant or unnecessary information in the higher cortical areas. Sensory gating is generally studied using paired pulse inhibition, which compares the P50 components of the event-related potentials from two successive auditory stimuli (clicks) separated by 500 ms. Under normal conditions, P50 amplitude is reduced in response to the second stimulus, and this is attributed to adaptation by sensory gating. In a combined EEG and fMRI study, Bak et al. (107) suggested that the claustrum, together with the hippocampus, mediates the inhibitory processes of P50 suppression. In neurologically healthy human subjects, P50 amplitude decreased by $80-90 \%$ following the second pulse, whereas amplitude is reduced by only $10-20 \%$ in subjects with schizophrenia $(108,109)$. Reduced sensory gating is also seen in other psychotic processes (108), and is implicated in the formation of psychotic symptoms via changes in latent inhibition. Altered latent inhibition, in turn, is a predictor of medication efficacy for positive symptoms of psychosis $(8,110,111)$.

A similar paired-pulse inhibition (PPI) assay is widely used as an animal model for psychotic symptoms [reviewed in Forrest et al. (8) and Ratajczak et al. (112)]. Bortolato et al. (113) and Ruderman et al. (7) have worked on rat and mouse models, respectively, of psychosis induced by subcutaneous injection of selective KOR agonists, which disrupt acoustic PPI. In those experiments, PPI suppression was reversed by pretreatment with KOR antagonists, and also by the atypical (antiserotonergic and antidopaminergic) antipsychotics clozapine and AC90179 (a highly selective 5-HT2A receptor inverse agonist). Reversal was not observed with pretreatment using the antidopaminergic haloperidol. We are unaware of any studies that have specifically examined PPI-like effects in claustrum responses using animal models, although the time scale of claustrum responses to auditory stimuli in non-human primates overlaps the PPI interval (114), so such an experiment may be feasible in the future.

Sensory gating is also a key component of early attentional modulation and stimulus salience. Remedios et al. $(114,115)$ have suggested that the claustrum could be a detector of novel or salient sensory events, and this and other observations have led Goll et al. (27) to propose that one fundamental role of the claustrum may be modulation of selective attention. The interested reader is referred to their comprehensive review and analysis of the attention hypothesis for more information. This is an area ripe for experimental investigation, and future genetic knockout or transfection models will likely help to clarify the role of the claustrum in psychosis and sensory gating.

\section{CLAUSTRUM AS A COMPONENT OF BEHAVIORAL AND PSYCHOLOGICAL- LEVEL MODELS OF DELUSIONS}

Two main characterizations of delusions as a psychological/ behavioral phenomenon have been proposed in recent years: (1) delusions as an error of predictive modeling or validity testing of external stimuli, and (2) delusions as abnormalities of stimulus salience. The widespread connectivity and polymodal nature of the claustrum is consistent with a role in either of these models, as described below.

Llinas and Roy (116) have modeled the mammalian brain as a Bayesian prediction engine. In this construct, behavior during normal function includes generation of predictive models of motor outcomes. Llinas and Roy suggested that these predictive models act to compare incoming sensory signals against internal, learned representations of the external world. This system allows feedback analysis of the effects of motor actions (the outward manifestations of behavior), as well as predictions regarding possible outcomes of motor action. Learned representations form the prior knowledge required for a Bayesian system, and as new observations occur, previous judgments are reviewed, giving an increasingly low weight to the prior beliefs. This has the effect of minimizing the prediction error.

Under the model of Llinas and Roy (116), sensory-motor representations are encoded in the oscillatory dynamics of the thalamocortical circuit, and individual variations in thought and behavior could exist as stochastic variances in oscillatory behavior across thalamocortical networks. In several key ways, the claustrum offers a more plausible locus for this activity. Claustrum-cortex connectivity offers a relatively uniform "path length" between diverse areas of the cerebral cortex (21), and the sheet like and elongated geometry of this structure may facilitate communication between, e.g., prefrontal areas and parietal and occipital regions of cortex. Moreover, the thalamocortical oscillatory model necessitates a functional connection between modality specific areas, e.g., primary visual cortex (V1) and lateral geniculate nucleus (LGN), with polymodal information mediated through the "non-specific" nuclei of the thalamus $(117,118)$. In contrast, Pearson et al. (32) have demonstrated that regions of cortex that are interconnected, even if they do not share the same sensory modality or internal vs. external representation, exhibit overlapping patterns of structural connectivity in the primate claustrum. This suggests that rapid, polymodal, internal vs. external computations could be efficiently mediated by the claustrum. Corlett et al. (119-121) have suggested that delusions arise from responses of brain circuits to prediction errors. Thus, in delusional patients, bottom-up signals (new information brought by external sensory experiences) are aberrant, indicating to the patient that prior beliefs are false and should be adjusted to explain the world. In this case, the patient does not take past experiences appropriately 
into account. Finally, whereas lesion studies are problematic at the behavioral/psychological level for the reasons outlined in previous sections, it is interesting to note that lesions of the thalamus are not generally associated with psychotic symptoms, in contrast to the lesions of the claustrum-pulvinar-insula region described above.

Gandola et al. (12) performed a lesion-mapping analysis of cases of somatoparaphrenia (delusional belief that a paralyzed limb or side of the body belongs to another individual) and identified a region of maximum overlap across patients that involved both a portion of the lateral thalamus, as well as the claustrum-pulvinar-insula region. Yet again, these authors did not specify damage to the claustrum, although it is implicit in the published figures, and implies damage to the adjacent white matter tracts as well. Thus, it is impossible to state conclusively whether damage to either thalamocortical or claustrum-cortical circuits in isolation could result in delusions. We predict that this ambiguity will be resolved as the anatomy and centrality of connections of the claustrum become more widely known to investigators and clinicians.

The second major psychological/behavioral model of delusional thinking is the suggestion by Coltheart (122) and Coltheart et al. (123), among others, that delusions result from an imbalance between the production of false beliefs (possibly resulting from a disturbance of stimulus salience by increased mesolimbic dopamine activity) and the inability to assess the validity or reality of these beliefs. They predict that the main cortical loci of this reality testing resides in the right PFC [reviewed in Coltheart et al. (123)]. Recent connectivity studies in non-human primates have identified a dense, overlapping pattern of connections between several areas of the dorsolateral PFC and the rostral and mid-ventral levels of the claustrum $(23,124)$. This circuit provides a plausible anatomical substrate for the reality testing model, and will, for the first time, provide a means of targeting specific regions of the claustrum for experimental manipulations and high resolution imaging. This, in turn, will facilitate experimental examination of hypotheses related to a role for the claustrum in the schema described above.

\section{REFERENCES}

1. van Os J, Kapur S. Schizophrenia. Lancet (2009) 374(9690):635-45. doi:10.1016/S0140-6736(09)60995-8

2. Garety PA, Freeman D. The past and future of delusions research: from the inexplicable to the treatable. Br J Psychiatry (2013) 203(5):327-33. doi:10.1192/bjp.bp.113.126953

3. Verdoux H, Maurice-Tison S, Gay B, Van Os J, Salamon R, Bourgeois ML. A survey of delusional ideation in primary-care patients. Psychol Med (1998) 28(1):127-34. doi:10.1017/S0033291797005667

4. Freeman D. Delusions in the nonclinical population. Curr Psychiatry Rep (2006) 8(3):191-204. doi:10.1007/s11920-006-0023-1

5. Varghese D, Scott J, McGrath J. Correlates of delusion-like experiences in a non-psychotic community sample. Aust N Z J Psychiatry (2008) 42(6):505-8. doi:10.1080/00048670802050595

6. Schmack K, Gomez-Carrillo de Castro A, Rothkirch M, Sekutowicz M, Rossler $\mathrm{H}$, Haynes JD, et al. Delusions and the role of beliefs in perceptual inference. J Neurosci (2013) 33(34):13701-12. doi:10.1523/JNEUROSCI.1778-13.2013

7. Ruderman MA, Powell SB, Geyer MA. A kappa opioid model of atypical altered consciousness and psychosis: U50488, DOI, AC90179 effects

\section{CONCLUSION}

Here, we have summarized the suggestive, but not conclusive, body of evidence that implicates the claustrum in the underlying pathology of delusional thinking. We consider this report a successful foray if clinicians, in particular those who concentrate on patient populations where delusions are common, incorporate the claustrum and the possibility of claustrum damage into their understanding of the disease processes. Several hypothetical functions of the claustrum have been proffered, any of which could affect delusional pathologies. It is of course possible that these suggestions could be rendered moot should ongoing research identify an unrelated function of the claustrum in normal and/ or pathological behavior. However, the consistency of delusions as an accompanying feature of such a wide range of syndromes in which structural changes in the claustrum have been reported suggests strongly to us that this is a necessary and potentially quite fruitful line of inquiry for future studies. Parallel advances in understanding the basic science of the claustrum, including its neurochemistry, cytoarchitecture, and functional connectivity, will likely yield potential therapeutic targets, including both surgical and pharmacologic approaches for ameliorating disease associated with alterations of claustrum function. We suggest here that delusions may represent an outward manifestation of one such disease process, secondary to a structural or functional disturbance of information processing of the claustrum.

\section{ACKNOWLEDGMENTS}

The authors thank Larry Edelstein, who provided helpful critiques of the draft manuscript. Drs. Larry Edelstein, Annalena Venneri, and Michael Shanks provided helpful comments regarding claustrum dysfunction and Alzheimer's disease. The Nissl images in Figure 1 were used with the kind permission of Dr. John I. Johnson, curator of the Biodiversity Brain Bank (http://www.brains.rad. msu.edu). Ms. Maree Reser and Dr. Elizabeth Zavitz provided invaluable assistance with proofreading of the draft manuscript. DR is supported by NHMRC Discovery Project Grant 1068140.

on prepulse inhibition and locomotion in mice. J Young Investig (2009) 19(13): 1-7.

8. Forrest AD, Coto CA, Siegel SJ. Animal models of psychosis: current state and future directions. Curr Behav Neurosci Rep (2014) 1(2):100-16. doi:10.1007/ s40473-014-0013-2

9. Brent BK, Seidman LJ, Coombs G III, Keshavan MS, Moran JM, Holt DJ. Neural responses during social reflection in relatives of schizophrenia patients: relationship to subclinical delusions. Schizophr Res (2014) 157(1-3):292-8. doi:10.1016/j.schres.2014.05.033

10. Whitford TJ, Lee SW, Oh JS, de Luis-Garcia R, Savadjiev P, Alvarado JL, et al. Localized abnormalities in the cingulum bundle in patients with schizophrenia: a diffusion tensor tractography study. NeuroImage Clin (2014) 5:93-9. doi:10.1016/j.nicl.2014.06.003

11. Devine MJ, Bentley P, Jones B, Hotton G, Greenwood RJ, Jenkins IH, et al. The role of the right inferior frontal gyrus in the pathogenesis of post-stroke psychosis. J Neurol (2014) 261(3):600-3. doi:10.1007/s00415-014-7242-x

12. Gandola M, Bottini G, Zapparoli L, Invernizzi P, Verardi M, Sterzi R, et al. The physiology of motor delusions in anosognosia for hemiplegia: implications for current models of motor awareness. Conscious Cogn (2014) 24:98-112. doi:10.1016/j.concog.2014.01.001 
13. Thiel CM, Studte S, Hildebrandt H, Huster R, Weerda R. When a loved one feels unfamiliar: a case study on the neural basis of Capgras delusion. Cortex (2014) 52:75-85. doi:10.1016/j.cortex.2013.11.011

14. Radaelli D, Poletti S, Gorni I, Locatelli C, Smeraldi E, Colombo C, et al. Neural correlates of delusion in bipolar depression. Psychiatry Res (2014) 221(1):1-5. doi:10.1016/j.pscychresns.2013.10.004

15. Speechley WJ, Woodward TS, Ngan ET. Failure of conflict to modulate central executive network activity associated with delusions in schizophrenia. Front Psychiatry (2013) 4:113. doi:10.3389/fpsyt.2013.00113

16. Griffiths O, Langdon R, Le Pelley ME, Coltheart M. Delusions and prediction error: re-examining the behavioural evidence for disrupted error signalling in delusion formation. Cogn Neuropsychiatry (2014) 19(5):439-67. doi:10.10 80/13546805.2014.897601

17. Collin G, Kahn RS, de Reus MA, Cahn W, van den Heuvel MP. Impaired rich club connectivity in unaffected siblings of schizophrenia patients. Schizophr Bull (2014) 40(2):438-48. doi:10.1093/schbul/sbt162

18. Vicq-d'Azyr F, Didot FA, Briceau A. Traité d'anatomie et de physiologie: avec des planches coloriées représentant au naturel les divers organes de l'homme et des animaux: De l'imprimerie de Franç. AMB. Didot l'aîné (1786).

19. Edelstein LR, Denaro FJ. The claustrum: a historical review of its anatomy, physiology, cytochemistry and functional significance. Cell Mol Biol (2004) 50(6):675-702. doi:10.1170/T558

20. Smythies J, Edelstein L, Ramachandran V. The Claustrum: Structural, Functional, and Clinical Neuroscience. San Diego, CA: Elsevier: Academic Press (2014). 393 p.

21. Crick FC, Koch C. What is the function of the claustrum? Philos Trans R Soc Lond B Biol Sci (2005) 360(1458):1271-9. doi:10.1098/rstb.2005.1661

22. Smythies J, Edelstein L, Ramachandran V. The functional anatomy of the claustrum: the net that binds. WebmedCentral NEUROSCIENCES (2012) 3(3):WMC003182. doi:10.9754/journal.wmc.2012.003182

23. Reser DH, Richardson KE, Montibeller MO, Zhao S, Chan JM, Soares JG, et al. Claustrum projections to prefrontal cortex in the capuchin monkey (Cebus apella). Front Syst Neurosci (2014) 8:123. doi:10.3389/fnsys.2014.00123

24. Menon V, Uddin LQ. Saliency, switching, attention and control: a network model of insula function. Brain Struct Funct (2010) 214(5-6):655-67. doi:10.1007/s00429-010-0262-0

25. Seeley WW, Menon V, Schatzberg AF, Keller J, Glover GH, Kenna H, et al. Dissociable intrinsic connectivity networks for salience processing and executive control. J Neurosci (2007) 27(9):2349-56. doi:10.1523/ JNEUROSCI.5587-06.2007

26. Goulden N, Khusnulina A, Davis NJ, Bracewell RM, Bokde AL, McNulty JP, et al. The salience network is responsible for switching between the default mode network and the central executive network: replication from DCM. Neuroimage (2014) 99:180-90. doi:10.1016/j.neuroimage.2014.05.052

27. Goll Y, Atlan G, Citri A. Attention: the claustrum. Trends Neurosci (2015) 38(8):486-95. doi:10.1016/j.tins.2015.05.006

28. Bota M, Sporns O, Swanson LW. Architecture of the cerebral cortical association connectome underlying cognition. Proc Natl Acad Sci U S A (2015) 112(16):E2093-101. doi:10.1073/pnas.1504394112

29. Olson CR, Graybiel AM. Sensory maps in the claustrum of the cat. Nature (1980) 288(5790):479-81. doi:10.1038/288479a0

30. Sherk H, LeVay S. Visual claustrum: topography and receptive field properties in the cat. Science (1981) 212(4490):87-9. doi:10.1126/science.7209525

31. Li ZK, Takada M, Hattori T. Topographic organization and collateralization of claustrocortical projections in the rat. Brain Res Bull (1986) 17(4):529-32. doi:10.1016/0361-9230(86)90220-0

32. Pearson RC, Brodal P, Gatter KC, Powell TP. The organization of the connections between the cortex and the claustrum in the monkey. Brain Res (1982) 234(2):435-41. doi:10.1016/0006-8993(82)90883-6

33. Druga R. The structure and connections of the claustrum. In: Smythies J, Edelstein L, Ramachandran V, editors. The Claustrum: Structural, Functional, and Clinical Neuroscience. San Diego, CA: Academic Press; Elsevier, Inc. (2014). p. 29-84.

34. Fernandez-Miranda JC, Rhoton AL Jr, Alvarez-Linera J, Kakizawa Y, Choi C, de Oliveira EP. Three-dimensional microsurgical and tractographic anatomy of the white matter of the human brain. Neurosurgery (2008) 62(6 Suppl 3):989-1026. doi:10.1227/01.neu.0000333767.05328.49

35. Milardi D, Bramanti P, Milazzo C, Finocchio G, Arrigo A, Santoro G, et al. Cortical and subcortical connections of the human claustrum revealed in vivo by constrained spherical deconvolution tractography. Cereb Cortex (2015) 25(2):406-14. doi:10.1093/cercor/bht231

36. Morys J, Narkiewicz O, Wisniewski HM. Neuronal loss in the human claustrum following ulegyria. Brain Res (1993) 616(1-2):176-80. doi:10.1016/0006-8993(93)90207-4

37. Morys J, Sloniewski P, Narkiewicz O. Somatosensory evoked potentials following lesions of the claustrum. Acta Physiol Pol (1988) 39(5-6):475-83.

38. Sloniewski P, Morys J. The claustrum as the structure related to the somatosensory evoked potentials in the man. Verh Anat Ges (1987) 81:891-2.

39. Koubeissi MZ, Bartolomei F, Beltagy A, Picard F. Electrical stimulation of a small brain area reversibly disrupts consciousness. Epilepsy Behav (2014) 37:32-5. doi:10.1016/j.yebeh.2014.05.027

40. Deutch AY, Mathur BN. Editorial: the claustrum: charting a way forward for the brain's most mysterious nucleus. Front Syst Neurosci (2014) 9:103. doi:10.3389/fnsys.2015.00103

41. Mathur BN, Caprioli RM, Deutch AY. Proteomic analysis illuminates a novel structural definition of the claustrum and insula. Cereb Cortex (2009) 19(10):2372-9. doi:10.1093/cercor/bhn253

42. Torgerson CM, Van Horn JD. A case study in connectomics: the history, mapping, and connectivity of the claustrum. Front Neuroinformatics (2014) 8:83. doi:10.3389/fninf.2014.00083

43. Reser DH, Kolbe SC. "Functional connectivity of the claustrum during resting wakefulness," in Society for Neuoscience Annual Meeting, Washington, DC (2014).

44. Kapakin S. The claustrum: three-dimensional reconstruction, photorealistic imaging, and stereotactic approach. Folia Morphol (2011) 70(4):228-34.

45. Torgerson CM, Irimia A, Goh SY, Van Horn JD. The DTI connectivity of the human claustrum. Hum Brain Mapp (2015) 36(3):827-38. doi:10.1002/ hbm.22667

46. Keilholz SD. The neural basis of time-varying resting-state functional connectivity. Brain Connectivity (2014) 4(10):769-79. doi:10.1089/brain.2014.0250

47. Greicius MD, Krasnow B, Reiss AL, Menon V. Functional connectivity in the resting brain: a network analysis of the default mode hypothesis. Proc Natl Acad Sci U S A (2003) 100(1):253-8. doi:10.1073/pnas.0135058100

48. Raichle ME. The brain's default mode network. Annu Rev Neurosci (2015) 38:433-47. doi:10.1146/annurev-neuro-071013-014030

49. Sridharan D, Levitin DJ, Menon V. A critical role for the right fronto-insular cortex in switching between central-executive and default-mode networks. Proc Natl Acad Sci U S A (2008) 105(34):12569-74. doi:10.1073/ pnas.0800005105

50. Jukuri T, Kiviniemi V, Nikkinen J, Miettunen J, Maki P, Mukkala S, et al. Central executive network in young people with familial risk for psychosis - the Oulu Brain and Mind Study. Schizophr Res (2015) 161(2-3):177-83. doi:10.1016/j.schres.2014.11.003

51. Mantini D, Gerits A, Nelissen K, Durand JB, Joly O, Simone L, et al. Default mode of brain function in monkeys. J Neurosci (2011) 31(36):12954-62. doi:10.1523/JNEUROSCI.2318-11.2011

52. Belcher AM, Yen CC, Stepp H, Gu H, Lu H, Yang Y, et al. Large-scale brain networks in the awake, truly resting marmoset monkey. J Neurosci (2013) 33(42):16796-804. doi:10.1523/JNEUROSCI.3146-13.2013

53. Schwarz AJ, Gass N, Sartorius A, Risterucci C, Spedding M, Schenker E, et al. Anti-correlated cortical networks of intrinsic connectivity in the rat brain Brain Connect (2013) 3(5):503-11. doi:10.1089/brain.2013.0168

54. Stafford JM, Jarrett BR, Miranda-Dominguez O, Mills BD, Cain N, Mihalas $\mathrm{S}$, et al. Large-scale topology and the default mode network in the mouse connectome. Proc Natl Acad Sci US A (2014) 111(52):18745-50. doi:10.1073/ pnas.1404346111

55. Sierakowiak A, Monnot C, Aski SN, Uppman M, Li TQ, Damberg P, et al. Default mode network, motor network, dorsal and ventral basal ganglia networks in the rat brain: comparison to human networks using resting state-fMRI. PLoS One (2015) 10(3):e0120345. doi:10.1371/journal. pone. 0120345

56. Satterthwaite TD, Baker JT. How can studies of resting-state functional connectivity help us understand psychosis as a disorder of brain development? Curr Opin Neurobiol (2015) 30:85-91. doi:10.1016/j. conb.2014.10.005

57. Torgerson CM, Van Horn JD. A case study in connectomics: the history, mapping, and connectivity of the claustrum. Front Neuroinform (2014) 8:83 doi:10.3389/fninf.2014.00083. eCollection 2014. 
58. Ishii K, Tsuji H, Tamaoka A. Mumps virus encephalitis with symmetric claustrum lesions. AJNR Am J Neuroradiol (2011) 32(7):E139. doi:10.3174/ ajnr.A2603

59. Sperner J, Sander B, Lau S, Krude H, Scheffner D. Severe transitory encephalopathy with reversible lesions of the claustrum. Pediatr Radiol (1996) 26(11):769-71. doi:10.1007/BF01396197

60. Jacobson-McEwen SC, Connolly CG, Kelly AM, Kelleher I, O’Hanlon E, Clarke M, et al. Resting-state connectivity deficits associated with impaired inhibitory control in non-treatment-seeking adolescents with psychotic symptoms. Acta Psychiatr Scand (2014) 129(2):134-42. doi:10.1111/ acps. 12141

61. Cascella NG, Gerner GJ, Fieldstone SC, Sawa A, Schretlen DJ. The insula-claustrum region and delusions in schizophrenia. Schizophr Res (2011) 133(1-3):77-81. doi:10.1016/j.schres.2011.08.004

62. Bruen PD, McGeown WJ, Shanks MF, Venneri A. Neuroanatomical correlates of neuropsychiatric symptoms in Alzheimer's disease. Brain (2008) 131(Pt 9):2455-63. doi:10.1093/brain/awn151

63. Wolf RC, Huber M, Depping MS, Thomann PA, Karner M, Lepping P, et al. Abnormal gray and white matter volume in delusional infestation. Prog Neuropsychopharmacol Biol Psychiatry (2013) 46:19-24. doi:10.1016/j. pnpbp.2013.06.004

64. Bernstein HG, Ortmann A, Dobrowolny H, Steiner J, Brisch R, Gos T, et al. Bilaterally reduced claustral volumes in schizophrenia and major depressive disorder: a morphometric postmortem study. Eur Arch Psychiatry Clin Neurosci (2015): 1-9. doi:10.1007/s00406-015-0597-x

65. Menon M, Schmitz TW, Anderson AK, Graff A, Korostil M, Mamo D, et al. Exploring the neural correlates of delusions of reference. Biol Psychiatry (2011) 70(12):1127-33. doi:10.1016/j.biopsych.2011.05.037

66. Zhang X, Hannesson DK, Saucier DM, Wallace AE, Howland J, Corcoran ME. Susceptibility to kindling and neuronal connections of the anterior claustrum. J Neurosci (2001) 21(10):3674-87. doi:10.1.1.324.8023

67. Dodgson MC. A congenital malformation of insular cortex in man, involving the claustrum and certain subcortical centers. J Comp Neurol (1955) 102(2):341-64. doi:10.1002/cne.901020203

68. Fawcett E. Brain with an enormously enlarged claustrum. J Anat Physiol (1912) 47:116-8.

69. McKay R, Cipolotti L. Attributional style in a case of Cotard delusion. Conscious Cogn (2007) 16(2):349-59. doi:10.1016/j.concog.2006.06.001

70. Shoji H, Asaoka K, Ayabe M, Ichiyama T, Sakai K. Non-herpetic acute limbic encephalitis: a new subgroup of limbic encephalitis? Intern Med (2004) 43(4):348. doi:10.2169/internalmedicine.43.348

71. Ishida H, Hattori H, Takaura N, Yoshida T, Tanaka K, Otani S, et al. [A child with non-herpetic acute limbic encephalitis affecting the claustrum and hippocampus]. No To Hattatsu (2006) 38(6):443-7.

72. Matsuzono K, Kurata T, Deguchi S, Yamashita T, Deguchi K, Ikeda Y, et al. Two unique cases with anti-glur antibody-positive encephalitis. Clin Med Insights Case Rep (2013) 6:113-7. doi:10.4137/CCRep.S11890

73. Chakraborty S, Singi SR, Pradhan G, Anantha Subramanya H. Neuro-cysticercosis presenting with single delusion: a rare psychiatric manifestation. Int J Appl Basic Med Res (2014) 4(2):131-3. doi:10.4103/2229-516X.136808

74. McMurtray A, Tseng B, Diaz N, Chung J, Mehta B, Saito E. Acute psychosis associated with subcortical stroke: comparison between basal ganglia and mid-brain lesions. Case Rep Neurol Med (2014) 2014:428425. doi:10.1155/2014/428425

75. Turkalj I, Stojanovic S, Petrovic K, Njagulj V, Mikov I, Spanovic M. Psychosis following stab brain injury by a billiard stick. Hippokratia (2012) 16(3):275-7.

76. Sener RN. The claustrum on MRI: normal anatomy, and the bright claustrum as a new sign in Wilson's disease. Pediatr Radiol (1993) 23(8):594-6. doi:10.1007/BF02014975

77. Sener RN. Lesions affecting the claustrum. Comput Med Imaging Graph (1998) 22(1):57-61. doi:10.1016/S0895-6111(97)00043-8

78. Huang CC, Chu NS. Psychosis and epileptic seizures in Wilson's disease with predominantly white matter lesions in the frontal lobe. Parkinsonism Relat Disord (1995) 1(1):53-8. doi:10.1016/1353-8020(95)00013-V

79. Bidaki R, Zarei M, Mirhosseini SM, Moghadami S, Hejrati M, Kohnavard M, et al. Mismanagement of Wilson's disease as psychotic disorder. Adv Biomed Res (2012) 1:61. doi:10.4103/2277-9175.100182
80. Grover S, Sarkar S, Jhanda S, Chawla Y. Psychosis in an adolescent with Wilson's disease: a case report and review of the literature. Indian J Psychiatry (2014) 56(4):395-8. doi:10.4103/0019-5545.146530

81. Demily C, Sedel F. Psychiatric manifestations of treatable hereditary metabolic disorders in adults. Ann Gen Psychiatry (2014) 13:27. doi:10.1186/ s12991-014-0027-x

82. Duffau H, Mandonnet E, Gatignol P, Capelle L. Functional compensation of the claustrum: lessons from low-grade glioma surgery. J Neurooncol (2007) 81(3):327-9. doi:10.1007/s11060-006-9236-8

83. Stahl SM. Stahl's Essential Psychopharmacology: Neuroscientific Basis and Practical Application. 4th ed. London: Cambridge University Press (2013).

84. Stahl SM. Beyond the dopamine hypothesis to the NMDA glutamate receptor hypofunction hypothesis of schizophrenia. CNS Spectr (2007) 12(4):265-8.

85. He L, Di Monte DA, Langston JW, Quik M. Autoradiographic analysis of N-methyl-D-aspartate receptor binding in monkey brain: effects of 1-methyl-4-phenyl-1,2,3, 6-tetrahydropyridine and levodopa treatment. Neuroscience (2000) 99(4):697-704. doi:10.1016/S0306-4522(00)00235-9

86. Meoni P, Mugnaini M, Bunnemann BH, Trist DG, Bowery NG. [3H]MK-801 binding and the mRNA for the NMDAR1 subunit of the NMDA receptor are differentially distributed in human and rat forebrain. Brain Res Mol Brain Res (1998) 54(1):13-23. doi:10.1016/S0169-328X(97)00289-1

87. Lisman J, Yasuda R, Raghavachari S. Mechanisms of CaMKII action in long-term potentiation. Nat Rev Neurosci (2012) 13(3):169-82. doi:10.1038/ nrn3192

88. Morales M, Root DH. Glutamate neurons within the midbrain dopamine regions. Neuroscience (2014) 282C:60-8. doi:10.1016/j. neuroscience.2014.05.032

89. Haglund L, Kohler C, Ross SB, Kelder D. Forebrain projections of the ventral tegmentum as studied by axonal transport of $[3 \mathrm{H}]$ dopamine in the rat. Neurosci Lett (1979) 12(2-3):301-6. doi:10.1016/0304-3940(79)96079-8

90. Heimer L, Alheid GF, de Olmos JS, Groenewegen HJ, Haber SN, Harlan RE, et al. The accumbens: beyond the core-shell dichotomy. J Neuropsychiatry Clin Neurosci (1997) 9(3):354-81. doi:10.1176/jnp.9.3.354

91. Saddoris MP, Sugam JA, Cacciapaglia F, Carelli RM. Rapid dopamine dynamics in the accumbens core and shell: learning and action. Front Biosci (2013) 5:273-88. doi:10.2741/E615

92. Krystal JH, Perry EB Jr, Gueorguieva R, Belger A, Madonick SH, AbiDargham A, et al. Comparative and interactive human psychopharmacologic effects of ketamine and amphetamine: implications for glutamatergic and dopaminergic model psychoses and cognitive function. Arch Gen Psychiatry (2005) 62(9):985-94. doi:10.1001/archpsyc.62.9.985

93. Hyde TM, Ron MA. The secondary schizophrenias. 3rd ed. In: Weinberger DR, Harrison P, editors. Schizophrenia. Oxford: Wiley-Blackwell (2010).

94. Behrens MM, Ali SS, Dao DN, Lucero J, Shekhtman G, Quick KL, et al. Ketamine-induced loss of phenotype of fast-spiking interneurons is mediated by NADPH-oxidase. Science (2007) 318(5856):1645-7. doi:10.1126/ science. 1148045

95. Kamei S, Kuzuhara S, Ishihara M, Morita A, Taira N, Togo M, et al. Nationwide survey of acute juvenile female non-herpetic encephalitis in Japan: relationship to anti-N-methyl-D-aspartate receptor encephalitis. Intern Med (2009) 48(9):673-9. doi:10.2169/internalmedicine.48.1898

96. Hall H, Farde L, Halldin C, Hurd YL, Pauli S, Sedvall G. Autoradiographic localization of extrastriatal D2-dopamine receptors in the human brain using [125I] epidepride. Synapse (1996) 23(2):115-23. doi:10.1002/ (SICI) 1098-2396(199606)23:2<115::AID-SYN7>3.0.CO;2-C

97. Meador-Woodruff JH, Mansour A, Civelli O, Watson SJ. Distribution of D2 dopamine receptor mRNA in the primate brain. Prog Neuropsychopharmacol Biol Psychiatry (1991) 15(6):885-93. doi:10.1016/0278-5846(91)90016-T

98. Baizer J. The structure and connections of the claustrum: the neurochemical organization of the claustrum. In: Smythies J, Edelstein L, Ramachandran V, editors. The Claustrum: Structural, Functional, and Clinical Neuroscience. San Diego, CA: Academic Press (Elsevier) (2014). p. 85-118.

99. Mansour A, Fox CA, Meng F, Akil H, Watson SJ. Kappa 1 receptor mRNA distribution in the rat CNS: comparison to kappa receptor binding and prodynorphin mRNA. Mol Cell Neurosci (1994) 5(2):124-44. doi:10.1006/ mone.1994.1015

100. Slater P, Cross AJ. Autoradiographic distribution of dynorphin1-9 binding sites in primate brain. Neuropeptides (1986) 8(1):71-6. doi:10.1016/0143-4179(86)90067-3 
101. Sim-Selley LJ, Daunais JB, Porrino LJ, Childers SR. Mu and kappal opioid-stimulated [35S] guanylyl-5'-O-(gamma-thio)-triphosphate binding in cynomolgus monkey brain. Neuroscience (1999) 94(2):651-62. doi:10.1016/ S0306-4522(99)00344-9

102. Ragen BJ, Freeman SM, Laredo SA, Mendoza SP, Bales KL. Mu and kappa opioid receptor distribution in the monogamous Titi monkey (Callicebus cupreus): implications for social behavior and endocrine functioning. Neuroscience (2015) 290:421-34. doi:10.1016/j.neuroscience.2015.01.023

103. Quirion R, Pilapil C, Magnan J. Localization of kappa opioid receptor binding sites in human forebrain using [3H]U69,593: comparison with [3H]bremazocine. Cell Mol Neurobiol (1987) 7(3):303-7. doi:10.1007/BF00711306

104. Peckys D, Landwehrmeyer GB. Expression of mu, kappa, and delta opioid receptor messenger RNA in the human CNS: a 33P in situ hybridization study. Neuroscience (1999) 88(4):1093-135. doi:10.1016/S0306-4522(98)00251-6

105. Stiefel KM, Merrifield A, Holcombe AO. The claustrum's proposed role in consciousness is supported by the effect and target localization of Salvia divinorum. Front Integr Neurosci (2014) 8:20. doi:10.3389/fnint.2014.00020

106. Hooker JM, Xu Y, Schiffer W, Shea C, Carter P, Fowler JS. Pharmacokinetics of the potent hallucinogen, salvinorin $\mathrm{A}$ in primates parallels the rapid onset and short duration of effects in humans. Neuroimage (2008) 41(3):1044-50. doi:10.1016/j.neuroimage.2008.03.003

107. Bak N, Glenthoj BY, Rostrup E, Larsson HB, Oranje B. Source localization of sensory gating: a combined EEG and fMRI study in healthy volunteers. Neuroimage (2011) 54(4):2711-8. doi:10.1016/j.neuroimage.2010.11.039

108. FreedmanR,AdlerLE, WaldoMC,PachtmanE,FranksRD.Neurophysiological evidence for a defect in inhibitory pathways in schizophrenia: comparison of medicated and drug-free patients. Biol Psychiatry (1983) 18(5):537-51.

109. Wan L, Friedman BH, Boutros NN, Crawford HJ. P50 sensory gating and attentional performance. Int J Psychophysiol (2008) 67(2):91-100. doi:10.1016/j.ijpsycho.2007.10.008

110. Weiner I. The "two-headed" latent inhibition model of schizophrenia: modeling positive and negative symptoms and their treatment. Psychopharmacology (2003) 169(3-4):257-97. doi:10.1007/s00213-002-1313-x

111. Weiner I, Arad M. Using the pharmacology of latent inhibition to model domains of pathology in schizophrenia and their treatment. Behav Brain Res (2009) 204(2):369-86. doi:10.1016/j.bbr.2009.05.004

112. Ratajczak P, Wozniak A, Nowakowska E. Animal models of schizophrenia: developmental preparation in rats. Acta Neurobiol Exp (2013) 73(4):472-84.

113. Bortolato M, Aru GN, Frau R, Orru M, Fa M, Manunta M, et al. Kappa opioid receptor activation disrupts prepulse inhibition of the acoustic startle in rats. Biol Psychiatry (2005) 57(12):1550-8. doi:10.1016/j.biopsych.2005.02.030
114. Remedios R, Logothetis NK, Kayser C. Unimodal responses prevail within the multisensory claustrum. J Neurosci (2010) 30(39):12902-7. doi:10.1523/ JNEUROSCI.2937-10.2010

115. Remedios R, Logothetis NK, Kayser C. A role of the claustrum in auditory scene analysis by reflecting sensory change. Front Syst Neurosci (2014) 8:44. doi:10.3389/fnsys.2014.00044

116. Llinas RR, Roy S. The 'prediction imperative' as the basis for self-awareness. Philos Trans R Soc Lond B Biol Sci (2009) 364(1521):1301-7. doi:10.1098/ rstb.2008.0309

117. Ferrarelli F, Tononi G. The thalamic reticular nucleus and schizophrenia. Schizophr Bull (2011) 37(2):306-15. doi:10.1093/schbul/sbq142

118. Kimura A. Diverse subthreshold cross-modal sensory interactions in the thalamic reticular nucleus: implications for new pathways of cross-modal attentional gating function. Eur J Neurosci (2014) 39(9):1405-18. doi:10.1111/ ejn. 12545

119. Corlett PR, Frith CD, Fletcher PC. From drugs to deprivation: a Bayesian framework for understanding models of psychosis. Psychopharmacology (2009) 206(4):515-30. doi:10.1007/s00213-009-1561-0

120. Corlett PR, Taylor JR, Wang XJ, Fletcher PC, Krystal JH. Toward a neurobiology of delusions. Prog Neurobiol (2010) 92(3):345-69. doi:10.1016/j. pneurobio.2010.06.007

121. Corlett PR, Honey GD, Krystal JH, Fletcher PC. Glutamatergic model psychoses: prediction error, learning, and inference. Neuropsychopharmacology (2011) 36(1):294-315. doi:10.1038/npp.2010.163

122. Coltheart M. The neuropsychology of delusions. Ann N Y Acad Sci (2010) 1191:16-26. doi:10.1111/j.1749-6632.2010.05496.x

123. Coltheart M, Langdon R, McKay R. Delusional belief. Annu Rev Psychol (2011) 62:271-98. doi:10.1146/annurev.psych.121208.131622

124. Eradath MK, Abe H, Matsumoto M, Matsumoto K, Tanaka K, Ichinohe N. Anatomical inputs to sulcal portions of areas $9 \mathrm{~m}$ and $8 \mathrm{Bm}$ in the macaque monkey. Front Neuroanat (2015) 9:30. doi:10.3389/fnana.2015.00030

Conflict of Interest Statement: The authors declare that the research was conducted in the absence of any commercial or financial relationships that could be construed as a potential conflict of interest.

Copyright $(2) 2015$ Patru and Reser. This is an open-access article distributed under the terms of the Creative Commons Attribution License (CC BY). The use, distribution or reproduction in other forums is permitted, provided the original author(s) or licensor are credited and that the original publication in this journal is cited, in accordance with accepted academic practice. No use, distribution or reproduction is permitted which does not comply with these terms. 